\title{
PLUGGING INTO OFFSHORE OUTSOURCING OF SOFTWARE DEVELOPMENT: A MULTIPLE CASE STUDY
}

\author{
Yalaho, A., University of Jyväskylä, Finland, ayalaho@cc.jyu.fi
}

\begin{abstract}
This paper explores the practice and trends of offshore outsourcing of systems development in two countries; namely, Finland and India. In particular, it deliberates upon the driving forces and obstacles of the offshore outsourcing. The viewpoints of the participating companies were researched using a multiple case study method. The findings indicate that the imperative for engaging in offshore outsourcing systems development and the obstacles encountered do not depart from similar findings in information systems (IS) literature. However, a novel finding of this present study is the use of a software house (broker) on the Finnish side that acts a buffer for other local firms with little or no experience in offshore outsourcing. On the other hand, the Indian software house in this study engages in offshore systems development with their Finnish counterparts for reasons espoused in IS literature. Furthermore, the role of trust, the nature of the project outsourced and the importance of selecting the right partners are considered vital to the success of the arrangement. The implication of the study is that it enhances our knowledge of cross-cultural outsourcing in systems development, which may be useful to practitioners and academics alike.
\end{abstract}

Keywords: Information Technology (IT), Ethics, IT and Ethics

\section{INTRODUCTION}

The impact of the globalization of resources has led to dramatic increases in cross-country business cooperation. The global software industry is one business that has been experiencing exponential growth since the 1980s [1-4]. Within the global software industries, there are hosts of segments; for example, applications and systems development (SD), business process outsourcing (BPO) and so on. In this study, we discuss an arrangement involving SD between two countries - Finland and India. Realistically, the two countries have been noted as major players in the global software industry $[5,6]$. Importantly, outsourcing has become an appealing option to organizations operating within the global economy for a variety of reasons. Some of those include the desire to be competitive [7], occasioned by intense global competition, scarce human resources, cost reduction and time-to-market considerations and so on [8-11]. The outsourcing of software production and other systems development has, in recent decades, taken up global dimensions in which companies from the developed countries outsource information technology (IT) functions involving software development and maintenance, application development, business process maintenance, etc., to the developing countries $[6,12-$ 15]. More recently, the flow of traffic has seen organizations from developing nations outsourcing to Western-owned firms [16]. Furthermore, the milieu also include firms from the developed world scampering to establish offshore operations or presence either through joint ventures or technical collaborations with partners in the developing parts of the world $[17,18]$.

Offshore outsourcing of systems development refers to the business practice whereby a business entity in one country looks for a foreign vendor or partner in another country that has expertise in developing operations in IS/IT development that were previously performed in-house domestically. The term offshore, according to some authors, might have been used to implicitly describe non-traditional software development sites in developing countries [19]. However, recent trends $[20,21]$ offer a wider view of the definition. Countries such Ireland and Canada are also involved in offshore outsourcing. Also, Rajkumar and Mani [13]define offshore outsourcing as: "When the supplier of software development is from another country than the firm that decides to outsource information systems". Offshore outsourcing itself is couched in global IS/IT outsourcing, which describes the arrangement in which organizations' contract all or part of IS development and maintenance, application development and other IT operations to one or more foreign suppliers $[13,22,23]$. Global IS/IT outsourcing, in turn, stems from outsourcing, which is a term different authors have ascribed a variety of definitions and frameworks; for example, [24-26] views it in terms of the market - "market versus hierarchy and make-or-buy", whilst others describe it from the viewpoint of "vertical integration" [7,27].

Nonetheless, our literature review indicates that much attention has been paid to the various segments and examples of outsourcing, including offshore outsourcing in which anecdotal and empirical evidence have dealt with issues such as benefits, risks, management decisions and practices of outsourcing. . However, little attention seems to be paid to case studies involving cross-national arrangements in offshore systems development, especially where the expertise of a broker software 
house is employed in order to minimize the risks that might arise from an offshore outsourcing arrangement. Furthermore, very limited information regarding the Finnish customer perspective of offshore outsourcing has not been deliberated upon in IS literature. To that end, this present study aims to fill such gaps in research. In this paper, we will discuss findings relating to the practice, the driving forces and the inhibitors of offshore outsourcing at the country and organization levels in Finland and India. Thus, the main objective is to explore the initiation, practices and management of the offshore partnerships between the selected organizations in the two countries. This research paper is not aimed at presenting conceptual frameworks and models for offshore outsourcing as several already exist $[19,28$ 32]. Rather, this article sets out to explore these offshore partnerships through multiple case studies and presents its findings in tune with prior IS literature on offshore outsourcing of systems development. The rest of the paper is organized as follows: Section 2 by reviews the historical background and trends in outsourcing, including offshore outsourcing. Sub-sections 2.1 and 2.2 specifically deal with the software and the systems development industries in Finland and India. Drivers and inhibitors and sourcing strategies/relationships of offshore outsourcing are presented in Section 3. Section 4 covers the research methodology and the case analyses. Finally, the discussions and conclusion of the paper are presented in Section 5.

\section{Historical background, trends and practice of global outsourcing}

The historical roots of IT outsourcing can be traced to the 1960s when computer systems were physically bulky and large. Such computers, namely mainframe, were used for time-sharing services [33-35]. The expensive nature of such systems led many organizations to contract out routine data processing activities to large externally managed operators. The arrangement came to be known as facility management. The underlying motivation for businesses to outsource during this period was cost reduction. The 1970 s ushered in rapid progress in software and applications development with its associated huge costs. Many organizations could not meet the demands; as such, they had to resort to contract programming as a cost-effective measure.

The periods from the 1980 s to the present time offers a multitude of reasons for the spread and growth of outsourcing and offshore systems development. First of all, global expansion and diffusion of IT was a key factor. Secondly, shortage of skilled IT professionals in the developed countries was another catalyst for global IT outsourcing [36, 37]. Thirdly, the 'watershed' decision of Kodak to outsource its IT functions to IBM and DEC [38, 39] and the combined effect of the influence on managers, as well as the 'me-too' syndrome it generated, accelerated the practice of outsourcing [40, 41]. Fourthly, the dire economic conditions of the 1980s and 1990s that several organizations in the developed economies encountered, hastened the process of global IS/IT outsourcing. This is because cost savings measures became prominent issues to management facing intense competition locally and internationally. The need to look for competent and skilled foreign professionals capable of delivering quality IT services/products at a fraction of home market prices became the norm. Many firms jumped on the bandwagon of global IS/IT outsourcing [42]. Lastly, the availability of new software exporting nations, some possessing entrepreneurship and trading abilities quickened the practice [13, 20, 43]. Examples of such nations include Ireland, Israel, India, China, Hungary, Romania, Russia, Philippines, Bulgaria, Nigeria and others. Although many developing nations currently serve as the recipient country for systems development projects, India leads the pack in this regard. The Indian software industry is one of the fastest growing [44-46].

In fact, the taxonomy of the world's leading software exporting nations classifies India in the same group/tier as those of most OECD countries engaged in software production and export [6]. The forecast of the global software industry, according to the Gartner Dataquest[47] report, was expected to reach $\$ 76.1$ billion in 2003 fuelled by rising worldwide end-user spending on software. The research firm, International Data Corporation (IDC) [48] predicts that global IT spending will be higher in 2007 accounting for $6,6 \%$ compare to $6,3 \%$ in 2006. Software will lead the growth with $8 \%$ of the total and service will remain stable with $6 \%$. In the service sector, outsourcing will be exceptionally strong which will accelerate to $7,5 \%$ [48].

\section{Finland and the global software industry}

Global outsourcing of systems development is not a new phenomenon in Finland. In a research conducted by Apte et al. [34], it was shown that about $11.3 \%$ of Finnish companies in the survey alluded to some sort of global IS/IT outsourcing in their operations. The study also showed that software development and maintenance were the topmost outsourced functions. The innovative Finnish software industry has spawned advances in IT, which in turn has helped to sustain the growth of the software industry in the country [49, 50]. Finland's software market was estimated at about $\$ 1.3$ billion in 2002 [51]. Finnish is a developed economy with a relatively small population of only 5.2 million. Despite its small size, it has been identified as a high priority market for 
software and services for e-commerce [51]. The Finnish software industry, according to Eastern Michigan University publication [52] has the following characteristics and trends, expanding focus and application areas beyond traditional Information Communication and Technology (ICT); software market convergence, fast-growing number of new start-up software companies, increasing role of Webrelated software, fast-growing role of embedded software, increase in software exports, consolidation of the software industry (mergers, acquisitions) and increase of mobile software.

It is estimated that there are about 1100 companies, most of them very small, which have traditionally concentrated on serving Finnish customers with application development, customizing and system integration [53].The growth in the Finnish software industry has been accelerated further as a result of changes in recent years in Russia and the Baltic countries; Finland now serves as an excellent gateway to these emerging markets [52]. The export growth of the software industry has ranged between $40-60 \%$ in recent years and the future looks even better. Autere et al. [50] studied the competitiveness of the Finnish software industry, and regarded the speed of technological change, the degree of internationalization, and the supply of skilled labor to be crucial for Finnish success. Regardless of these limitations, Finland has remained in the forefront of ICT advances [54] and is rated a first-tier software exporting nation [20].

\section{India and the global software industry}

NASSCOM, the body that takes the pulse of the ICT industry in India, reported that in the course of 1997, more than 142 of the Fortune 500 companies outsourced their software requirements to India. The survey also indicates that the period beyond 1987 saw Indian software exports crossing US \$2.5 billion [55], to which software and other ICT services have been exported to over 102 countries [56]. By 2002 the amount of revenue made from software export had reached $\$ 6.2$ billion in 2002 (Economist, 2003) and $\$ 9.5$ billion in 2003 [57]. Similarly, the compound annual growth rate (CAGR) for the software industry in India, which was approximately $35 \%$ in the early 1990 s $[35,58]$ has been in the region of $52.6 \%$ for the last 5 years [55]In fact, the Indian software industry is one of the fastest growing sectors of the national economy [44-46]. India's exports of computer software, IT services and electronics products are projected to grow by around $30 \%$ during 2007 to US $\$ 32$ billion, according to EconomicTimes [46].

These six OECD countries: USA, Japan, UK, Germany, France and Italy, together have $73 \%$ of the market share of the worldwide software market.
Interestingly, India's software export to these countries is almost $83 \%$ of its total software exports $[35,55,59]$. Also, India has nearly $85 \%$ of global offshore technology outsourcing, and it is often called the "birthplace of offshore outsourcing" [60] perhaps as a result of the abundant availability of skilled IT professionals. According to NASSCOM [61] the total direct employment of IT professionals in India has grown from 830,000 in 2003-2004 to well over one million in 2004-2005. The industry employee base is estimated at nearly 1.3 million 2006. IT software and services added over 120,000, ITES-BPO added $\sim 100,000$ - total direct employment in the Indian IT-ITES has grown approximately from 284,000 in $1999-2000$ to $1,293,000$ in $2005-2006$. However, indirect employment attributed to IT-ITES was 3 million. Moreover, India is the preferred destination of most firms, including those from the OECD countries [62-64]. The reasons for its success on the offshore outsourcing scene includes the availability of skilled talents in software development $[3,13,21,63]$; the use of the English language in education, business and industry $[13,65]$; the Indian government policies and actions, for example the establishment of software technology parks equipped with state-of-the-art communication systems and facilities; and in addition, the Indian government provides tax breaks and subsidies [35, 65-67]. Another factor is the high standard and quality of Indian software houses [13, 17, 21, 60]. Lastly, cost reduction (prices) offerings, which, when compared to home offers in developed nations, might be $50-70 \%$ better $[21,60,63,65]$. The business of outsourcing (in particular offshore systems development) to India is not without its dark side. Some of the challenges include cultural, infrastructural, government politics, geo-political risk and so on $[68,69]$.

\section{The drivers and benefits of offshore outsourcing}

In order to adequately understand the trends in offshore outsourcing, it would be beneficial to discuss its driving forces. The reasons why firms embark on offshore outsourcing is because of the advantages it proffers the participants. The offshore drivers are presented in Table 1 using conceptual frameworks from IS literature.

\section{$<$ Insert Table 1 here $>$}

\section{The inhibitors and obstacles of offshore outsourcing}

Doing business across national borders poses a problem [70]. The types of obstacles or risks seen in offshore outsourcing are summarized in Table 2 below. 


\section{<Insert Table 2 here $>$}

\section{Sourcing relationships and strategies for offshore outsourcing}

A scan of extant literature shows that a wider range of arrangements between purchasers and service providers are available [14, 71, 72]. The options include arrangements such as short-term contracts, partnerships, and relationships with preferred and trusted suppliers, joint ventures, multiple vendor contracts and so on. Specifically, in relation to India, Khan et al. [73]identified the following: (a) wholly owned Indian subsidiary - the Indian software house sets up wholly owned facilities abroad to perform systems development processes; (b) joint ventures with local firms - this is a strategy used by Indian software houses to enter foreign markets and expand their business; (c) direct outsourcing - here, the foreign partner directly outsources its tasks to Indian software companies; (d) multiple outsourcing suppliers - foreign purchasers uses this strategy to spread their risks by outsourcing to many Indian software firms at the same time; (e) through a third party (agent) - such agents handle the relevant activities relating to outsourcing jobs, between the Indian software house and the foreign purchasers; and (f) body shopping - a term described by Lacity and Hirschheim, [41] as the management of a contract employee, usually programmers, by another company's employees. This is the starting route of most Indian software firms [73].

Kakabadse and Kakabadse[74]find that European companies tend to use sourcing relationships where preferred/trusted suppliers are involved, and the nature of the contract is usually performance-based and single. Partnership and joint ventures are among the least considered sourcing relationships. In the same manner, Krishna et al., [69]proposed a framework that could be useful in choosing projects to be outsourced where cross-cultural issues exist. They contend that 'culturally-neutral' software, such as embedded systems, may be less susceptible to cultural factors and more relationships may be required where leading-edge business system development is involved, and so on.

\section{RESEARCH METHODOLOGY}

\section{Case study analysis}

A qualitative based research aims at a holistic analysis of the phenomenon. It is believed to be good in describing and illuminating the context and conditions under which research is conducted [75]. According to Yin [76], (p13), "a case study is an empirical inquiry that investigates a contemporary phenomenon within its real-life context, especially when the boundaries between phenomenon and context are not clearly evident. This research requires current as well as past data. The case study method, therefore, appears to be the most suitable for this study. The main goal of the field study is to explore how (a) the offshore outsourcing project is managed from the perspective of both the vendor and the client. Yin [76], states that certain topics, such as organizations, processes, programs, institutions, and events, are suitably examined through the case study method. The focus of the investigation in this study is a 'process' analysis. This study uses a case study approach because it enables us to study the ITsupported offshore outsourcing process issues in natural settings.

Miles and Huberman [77] state that in a multiple case research "there is much potential for both greater explanatory power and greater generalization than what a single-case study can deliver". A multiple case study method is also less subject to bias than the single case study [76, 77]. Since a multiple case study design enhances the generalizability and reduces bias, this study uses a multiple case design. Another motivation for a multiple case study method is that a researcher has an opportunity to observe and analyze a phenomenon that might have been previously inaccessible to scientific investigation. According to Miles and Huberman [77], a cross-case analysis attempts to understand the processes and outcomes that occur across many cases, and to then develop more sophisticated descriptions and more powerful explanations. This study investigates IT-supported offshore outsourcing of software production process by using multiple cases through cross-case analysis. It examines the same phenomenon in different settings, systematically compares and contrasts the phenomenon across the cases, and it thus establishes generalizations in the findings. The researcher may identify the conditions under which these findings could occur.

A total of 10 companies were identified, from which four case companies were selected. Following Yin's [76]suggestion, special attention has been given to the selection of appropriate case companies. He maintains that the case companies selected must have already successfully executed the same process that is under investigation. The types of case companies that were selected for this study fit this profile, as they have already successfully executed several offshore outsourcing projects and heavily use ICTs in their international business operations. These companies are knowledgeable and willing to share their knowledge, opinions and insights.

The field study was conducted at four companies during recent years. Interviewing the right people was of significant importance to the quality and credibility of our research. We used a rich and 
flexible data gathering strategy that required finding a representative unbiased set of data. In gathering data we approached key informants from all the layers that had a stake in the implementation of ICTSUPIOSP. To ensure that we would get information and insights about the subject from a wide range of perspectives, we conducted interviews with the following types of people:

(1) Chief executive officer or top management; (2) business manager or officer working closely at the remote location; (3) outsourcing project manager; (4) outsourcing project coordinator; (5) persons involved in negotiating offshore contract deals; (6) persons involved in executing offshore outsourcing process; (7) IT manager; and (8) system analyst. Those interviewed were highly educated and had several years of experiences in the outsourcing field.

The main research questions, and the questionnaire guide that was developed, all acted as a basis for conducting the field study. The questionnaire guide was composed of open-ended and semi-structured questions. The information we sought was mostly unstructured and non-quantitative. Therefore, the primary data collection method we followed was semi-structured interviews. In addition, we asked the normal background information about the size and type of business, the affiliation and education level of those whom we interviewed.

In total, 5 to 8 people from each company were interviewed. The locations included St. PetersburgRussia, Helsinki-Finland, Jyväskylä-Finland, Bangalore-India, and Calcutta-India. Each interview lasted more than 3 hours. Each person was interviewed 3 to 5 times and each interview was fully transcribed. All the interview records were downloaded and the transcriptions saved in an Ms. Access research database. In addition, documents such as research reports, market research reports, annual reports, internal company magazines, releases and other archival materials from both the provider and client companies were collected. We also conducted over 35 interviews with other researchers and practitioners.

We maintained a consistent discipline of sharing the data as it was collected, holding regular meetings and communication through email and chat to enable a continuing critical assessment of the progress and to permit follow-ups where needed. We also assessed the quality of these interviews when analyzing the empirical findings.

\section{Data analysis}

Data analysis was done using the qualitative data analysis (QDA) software Nvivo7. The software program NVivo7 is a computerized tool that can assist a qualitative researcher for an effective management of large amounts of qualitative data [78,
79], 62]. The QDA software facilitates the analysis process [80]. In this study, we used this software for coding, linking codes and text segments, documenting variability in codes, creating memos, searching, editing and reorganizing, visualizing representation of the data, seeing patterns (e.g. in matrices, modeling networks or associations) and organizing findings $[77,78]$.

Miles and Huberman [77], (p.56) assert that "Coding is analysis". The systematic coding of text for data analysis is one of the essential parts of qualitative research [77, 78, 81]. This involves how to differentiate and combine the data one has retrieved and the reflections one makes about the information [77]. Codes enable one to organize the text of the transcripts and discover patterns within that organizational structure [82]. MacQueen et al [83] describe codes as building blocks for theory or model building and the foundation on which the analyst's arguments rest. Our analysis process was divided into several steps.

Firstly, the research framework and an interview guide were used to maintain the focus on data collection and to reduce the amount of material to be processed. In order to make data analysis both rigorous and effective, this study systematically deployed several strategies suggested by Nahar [84], Richards [78]The first step was informal data analysis that was performed during and immediately after each interview: (a) during each interview, ideas and references to the theory were written down as they occurred; (b) summarizing of interviews was done immediately after each interview; and (c) preliminary findings were identified from each summary.

Secondly, the interview summary and identification of each preliminary finding were useful for data reduction and conducting preliminary analysis. The second step was transcribing the tape-recorded interviews. This step was a more formal process compared with the first step. During this step, taperecorded interviews were thoroughly listened to and transcribed verbatim following a second listening. A third listening, where the transcribed texts were compared to the tapes, was also conducted.

Thirdly, a narrative from each interview was developed, and they were organized thematically. The themes included the phases of the IT-supported offshore outsourcing process, software production, project management and IT. The data was sorted according to the set themes, which allowed us to reduce the data. Each theme for all the narratives has been compared extensively. Similarities emerged from each interview. 


\section{Codebook Development}

Our codebook creation followed the step proposed by MacQueen et al [83]to ensure inter-coder reliability. We developed codes as a tree structure based on the literature review, the main research questions, and the conceptual model. Codes were selected to mark the existence of an item.

\section{Validity and Reliability}

To improve the reliability and validity of this research a number of measures were applied. First, the background theory and a questionnaire guide were used in order to deal with detailed documentation of the data and minimize errors and biases. The questionnaire guide was reviewed by our case companies, researchers, and practitioners. Second, interviewees selected were involved in the outsourcing process and possessed a vast knowledge of the phenomenon under investigation. Third, the concepts of this research were delineated to interviewees before conducting the interviews. Fourth, multiple data sources were included in this study in order to increase the validity of the research. The same questions were asked to all interviewees and the results were compared. The data was read several times to ensure familiarization. Multiple data sources were utilized in order to increase the reliability and validity of the research. Fifth, research results were compared with prior research in the international outsourcing field. Comparison was further made with available published materials of the case companies. These measures increase the external validity of the research and overcome the specific criticism that case studies are not easily open to generalization. Sixth, each case report was carefully edited and forwarded to interviewees to check for possible errors and omissions and to evaluate the validity of our interpretation of their 'story' [76, 85]. All the errors and omission were corrected and some statements were modified to reflect the true opinions and perceptions of the interviewees. Data and interpretations have been checked by the interviewees through a formal presentation, the checking of case reports, and through our senior collaborators and researchers in the outsourcing field. In addition, the original raw data were presented for the readers to see, which improves the internal validity of the study [86]. Finally, the research path for the case study method has been consistently documented to ensure reproducibility [76].To support the analysis, a number of quotations from the interviewees were included in the case analysis sections.

\section{Case descriptions: The organizations}

We used three case companies for this study and have referred to them as Company X-FIN, Company ZFIN and Company Y-IND in order to protect the confidentiality of the parties, as requested by the participants. Their profiles are presented thus:

\section{Company X-FIN}

This is a 4-year old Finnish company with its head office Helsinki. It was founded by venture capital funds. Basically, it does systems development locally and also acts as an offshore outsourcing broker house that assists local firms to select foreign offshore partners. Upon selecting foreign partners, it also provides cultural and communication training for employees of the foreign company. It helps to procure visas and work permits for foreign clients. The company, as part of its duties, evaluates the performances of all parties using agreed deliverables and milestones. Further, it handles payments and contracting between the foreign suppliers and local businesses. It has executed many international outsourcing projects and possesses experience in its field of business. It engages in offshore outsourcing in embedded systems, image processing and systems/applications development.

\section{Company Y-IND}

This 6-year old Indian software development house was formed by venture capital funds. It is has branches in the US and the UK. It possesses SEI CMM 4 and ISO standards; its CAGR is more than $30 \%$. It has expertise in IT applications consulting, systems integration and development, and application development. It is a medium-sized company and prides itself as a strategic partner capable of guaranteeing appreciable cost reduction, high quality products and innovation.

\section{Company Z-FIN}

Company Z-FIN is a 5-year old local business in Finland. It develops hi-tech software products for the local market. It has an in-house systems development unit, but outsources some functions to other local companies. Its business areas include the development of image processing equipment, audio/video systems development and other allied products.

\section{Strategic reasons for engaging in offshore outsourcing and obstacles}

In order to make an outsourcing decision, many organizations often advance a variety of reasons. 
When the participants were asked to comment on why they resorted to the option, they gave the following responses:

".....The shortage of talented software professionals in the Western countries including Finland was the main reason why our local customers wanted to hire foreign professionals from India and Russia in order to block the gaps created by such shortages in skilled IT professionals. ... Finding all the talents from within a small country like ours is almost impossible." (Project coordinator, Company X-FIN)

"We are a medium-sized company. Our employees number hundreds all over the world, where we operate more than 10 development centres. Our strategic intent is built on working with our clients to primarily reduce costs and providing fast turnaround time in systems development." (Onsite Manager, Company Y-IND)

“...We have a need for specific talents and we contacted our local partners who in turn found such skills for us from India." (Business Manager, Company Z-Fin)

Several IS and other trade literature often report costreductions imperative for offshore outsourcing. An interviewee from Company X-FIN elaborated on cost advantages vis-à-vis IT skills requirement with these comments:

"Our main objective is not about cost advantage; rather, we place more importance on skills." (Head, Business Development; Company X-FIN)

Personnel from the offshore software house added: "We [Company Y-IND] do business with several companies from many parts of the world; some of the clients include large multinationals. Providing high quality product at a reduced cost is our mission. .... Customer satisfaction is our mantra." (Onsite Manager, Company Y-IND)

"Our company is flexible. It is our ultimate passion to continuously adapt our expertise in the changing IT landscape. We regularly update the skill level of our employees in cuttingedge technologies on the major OS platforms. Our flexibility extends to seamless innovation with our partners. (Project Manager; Company Y-IND)

This is consistent with the earlier findings as to why Finnish firms engage in global IS/IT outsourcing. In comparison with the USA, Japan or other developed nations, organizations in Finland tend to attach less significance to cost-saving benefit [34]. On the other hand, India seems to have built its systems development industry on cost reduction advantages $[5,13,14,37,65]$. However, the overriding effect of required IT skills facilitates this particular arrangement, as illustrated by the commentary below:

"Our expertise in cutting-edge technologies is superb, and we possess up-to-date management skills in IT/IS project development and management; which is in high demand everywhere." (Project Manager, Company Y-IND)

With regard to the prevailing obstacles facing the participants, excerpts from their responses are provided below:

"The main obstacle that we face is found in cultural differences. Though our own people speak English and our Indian partners do also; more often than not we find ourselves spending time trying to iron out minor issues." (General Manager; Company X-FIN)

"From time to time, we've noticed that though we all communicate in English with our Indian programmers, communicating is often not easy because of the way words are pronounced.” (Project Manager, Company Z-FIN)

"....At the outset of a new project especially, when we have new foreign houses, the tension is usually high because we are not familiar with their styles nor are they with ours. It takes time for confidence to develop.... Patience and flexibility helps us to overcome this period." (General Manager; Company X-FIN)

“....Occasionally, we encounter difficulties in getting out our staff over to Finland because of visa problems. Such does cause unnecessary delays in the project. Also, at the individual level, our workers find adapting to the new culture hectic" (Onsite Manager, Company Y-IND)

The companies did not mention telecommunication problems as the different entities in the arrangement use telecommunication including satellite, and the Internet for communication purposes.

\section{The Selection Process}

The selection process starts with the local firm contacting the broker firm to help it contract an offshore development house. The goals and needs of the local firm(s) are assessed, and the local firm is asked to fill-in a Request for Proposal (RFP). Formal meeting are made between the two local parties. Thereafter, the broker house searches its databases for suitable offshore developers. After a short period, suitable foreign partners are found and contacted, and the foreign software houses are asked to fill in their own RFP. The broker house carries out further analyses and when a perfect match is achieved; then the two companies - the local Finnish company and 
the offshore software house are linked up and contracts signed. Payment for the job done usually goes through the broker house, which also monitors the progress of the deliverables. Interestingly, the founders of Company X-FIN have personal and working experiences in India. The company also has offices in Russia. First of all, the company rates the countries from which the offshore software houses are based on several factors; namely, socio-political considerations, the pool of skilled software professionals, relative costs, availability of telecommunication infrastructure and IT skills. The importance of political stability in the selection of providers' countries is illustrated by the comments made by one participant.

"We once negotiated an offshore outsourcing business deal with a local firm's CTO, but it was stopped by the CEO of the firm, who offered the conflict between Pakistan and India as his reason." (Head, Business Development; Company X-FIN)

The viewpoints of the other participating companies are presented thus:

"We tend to use vendors that can guarantee us or our local clients a good strategic alliance or partnership. A stable relationship with our domestic companies is an added advantage." (Head, Business Development; Company X-FIN)

"Our objective is aimed at providing both technological and cost advantages to our global clients .... In fact, our success achievement with our past clients set us apart, which we pride ourselves on, because we make the extra mile in creating lifelong partners." (Onsite Manager; Company YIND)

"We look for customers that won't cheat us; will pay us handsomely and will engage with repeat business with us." (Project Manager; Company Y-IND)

\section{Organizational-specificity factors}

The firm-specific comparisons are then made during the next stage, using factors such as software technological level, software methodology and standards used; the size of the company, labor costs, turnover or attrition of employees, reputation, relationships with major international players, location of key offices (image), and financial resources. The process of selecting partners in an offshore outsourcing arrangement is critical because getting the process right is of vital importance The management of Company X-FIN said that very often they thoroughly review the process both for local firms and foreign vendors. For instance, they said size plays a role in selecting partners because large companies tend to be saddled with bureaucracies. On the other hand, Company X-FIN places emphasis on knowing its partners. It believes that by doing so they will be in a position to know and eventually guarantee the quality of the job done. Above all, communication is important to Company X-FIN. The approach towards communication by the offshore house is illustrated by the claim below:

"There is daily communications between us and all the parties in the arrangement. We connect all the ends via leased line or VPN. Moreover, no email goes unanswered by our staff." (Project Manager, Company YIND)

\section{The place and role of contract}

The relevance of contract in software development and outsourcing has been widely discussed (see for example [87, 88]. Company X-FIN nevertheless believes that contract is no panacea to good partnership, though it may be useful in resolving any misunderstandings and conflicts, if they arise in the future. At times its management travel to the destination of the systems developers, say in India, or the representatives of the foreign company came to Finland. Usually, the contract is broken down into segments, which include profit-sharing and working conditions. There are clauses in the contract enabling changes to be made to it in the future. One interviewee offered further insights by commenting:

"The contract borders on how we work, share profits and handle bills. Then there is another agreement specific to the client's project, which we have a template for. Though we accommodate and introduce changes based on customers [foreign] suggestions" (Head, Business Development; Company X-FIN).

Besides its use of contract, Company X-FIN commented that they look for ways of building trust between their partners, both local and foreign, although it was said to be much easier with their local clients. Nonetheless, the role of trust [89] was stressed and taken to be of a higher order of importance than the contract itself. Company X-FIN believes that once trust is built, the relationship strengthens and the contract is almost forgotten. When asked about how Company X-FIN fares with both Finnish laws and the foreign ones, e.g. Indian, one participant responded:

"Our contract is largely drawn up using Finnish law. However, we employed a technology-savvy lawyer who helps us navigate some intricate details relating to law. Moreover, our foreign partners bring their own contracts and agreements about how they want work with us; we abstract relevant information from theirs and we 
marry it with our contract to produce a new agreement acceptable to both parties. We believe in partnership. We know also that there will be threats and sanctions, but on the whole, partnership means a win-win relationship." (Head, Business Development; Company X-FIN)

This finding is consistent with views that outsourcing is embedded in social relations, though it is driven by several reasons, one of which is economic [30, 90]. Importantly, the test of the contractual relationships is assessed from the delivered products and services. If this is successful, more projects are added; otherwise, alternatives, by switching providers, are sought [9]. The delivered products may be sent via telecommunications transmission or delivered on site. The payment is made by Company X-FIN to the foreign partner at the end of the month for completed jobs. The Head of Business Development commented that:

\begin{abstract}
"A third-of the payment is made at the outset of the project involving the design phase; another third is made out for the coding and the last third upon successful user acceptance testing" (Head, Business Development; Company X-FIN).
\end{abstract}

Nevertheless, when an offshore systems developer house presents a different payment regime, Company $\mathrm{X}-\mathrm{FIN}$ is flexible with its procedures.

\section{Managing relationships in offshore outsourcing}

The issue of managing relationships in offshore outsourcing systems development is paramount to all the parties involved, both local and foreign. A welloiled partnership is the key to a successful outsourcing arrangement [13, 31, 90]. Various models in managing information technology are discussed widely in IS literature (see for example [30]). Relationship management, as the Finnish party indicated, goes beyond the contract. It is essential for both the local firms and the foreign software house to have control and management structures for managing processes, people and technology. The management capability of Company X-FIN is the major factor that guaranteed its success as a broker house between Indian software houses and Finnish clients. Company X-FIN demonstrates its ability to manage the relationships between the offshore systems development and its local clients as follows: (1) Management structure: The organization manages working relationships with the foreign client and the local business separately. As the structure consists of parties with differing philosophies and cultures, it became imperative for Company X-FIN to profoundly understand this fundamental difference. The organization always sends a Project Coordinator to the sites - local and/or foreign, for long periods to facilitate deeper understanding of the business and culture of their partners. Moreover, such relationships engender trust between partners [89, 91]. (2) Effective Communication: This was seen by the interviewees as the most important ingredient to a successful partnership in offshore system development. One interviewee remarked:
"Through effectively managed communication we ensure that all parties' requirements are understood by all. We initiate video conferencing when issues on certain requirements appear unclear." (Project coordinator, Company X-FIN)

Information is freely shared between all the companies regarding the progress of the work. The management of Company X-FIN pays visits to the offshore software houses in order to assess the organizational cultures of the potential supplier. One interviewee said:

"We like dealing with people with international exposure, when we saw that key management personnel of our potential partners had worked in the US and Japan, we felt more at ease in dealing with them." (Head, Business Development; Company X-FIN)

(3) Learning: Company X-FIN acquires and accumulates knowledge over time by evaluating projects and listening to comments made by its local clients. This enables the company to gain useful experience in selecting future partners as well as avoiding negative occurrences. One interviewee said:

"Our learning curve for the projects we've been involved in is quite high. We usually look back at our previous projects and see what we got right and where we made mistakes. By doing so, we learn useful lessons that we bring to our future deals." (Head, Business Development; Company X-FIN).

\section{The systems development project}

The project implementation is such that a joint team is developed. Company X-FIN has its own project manager who is skilled in project management. Company Y-IND has it own onsite manager, who is responsible for administration and a project manager, who is a skilled systems developer who liaises with colleagues; namely, the project coordinator in India, on technical issues. Company Z-FIN has its own project manger, who oversees the activities of the onshore software developers, both local and foreign, for example, on project A. Company X-FIN controls the processes, manages the risks in the partnership and the arrangement, and makes sure that communication functions as well as it should. The project coordinator from Company X-FIN is responsible for this. Figure 1 illustrates the arrangement. The complexity of the project, the strategic nature of the systems and the level of inhouse expertise determine what project goes offshore or which ones are developed at onsite. The part that 
goes offshore we called project B; which is solely handled by the offshore developers. The progress of the job is shared by the two project coordinators. All parties seem to agree with the success of the outsourcing arrangements. The onsite manager of the Indian software house commented on the nature of the development environment by saying:

"We believe in leveraging collaborative Onsite-Offshore development for the benefit of our clients who are responsible for providing the appropriate development environment. Our own team works with the clients on aspects that are localized and some other parts are sent to our colleagues back at home" (Onsite Manager, Company Y-IND).

"In terms of the set tasks in our contract with the Indians, we've found no problems, as our milestones have been met and the quality of the job as we expected." (Project Manager, Company Y-IND)

Figure1. The Onshore-Offshore arrangement in SD between Indian and Finnish Partners

Figure1. The Onshore-Offshore arrangement in SD between Indian and Finnish Partners the Finnish software house include political stability in the offshore site; technical skills which rate higher than costs; and existing infrastructural facilities in the offshore country. In the same vein, the image of the company, size, financial stability, flexibility, management and relevant IT expertise are used in selecting partners for a job. The shortage of skilled IT professionals in a small country like Finland seems to be the main driver for offshore outsourcing, which incidentally, is different from the main reason given by other Western countries for engaging in offshore outsourcing. Cost advantages appear to be the most cited reasons for other Western countries, including the US. The Finnish companies in this study tend to use a single contract, in which performances or milestones are measured as a way of managing their outsourcing relationship with their foreign client. And, the type of project engaged in by the three companies in this study involves systems development bordering on embedded software, which was said to be "culture-neutral". This, perhaps, explains why the respondent in this study did not accentuate the impacts of cultural differences between workers from the two countries.

Nevertheless, the key finding of this work is that a company serving as a broker house was able to act as a buffer for local clients in the process. The

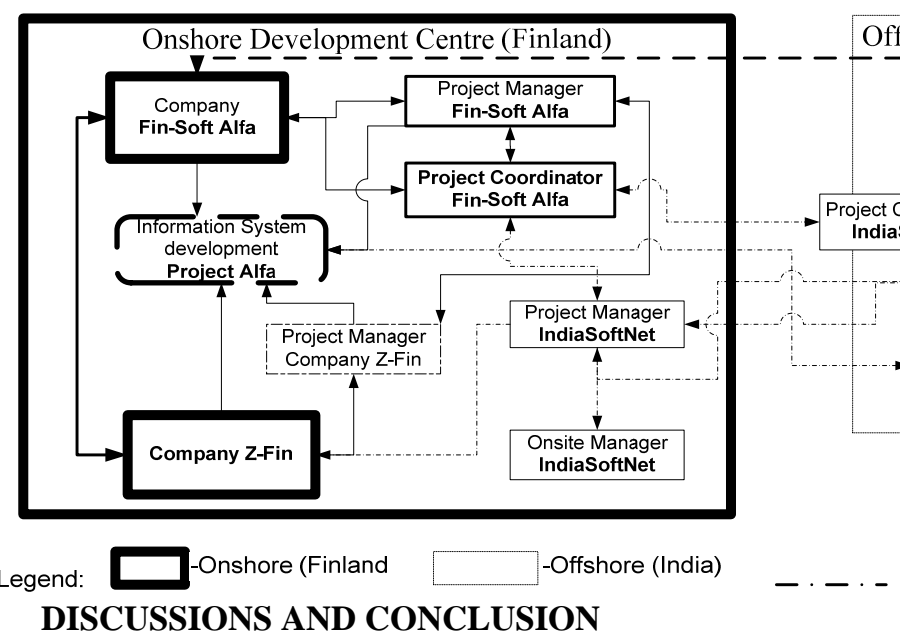

DISCUSSIONS AND CONCLUSION

Communication flow between onshore and offshore team accumulated expertise it gains is put to further use in sourcing potential partners from foreign lands for local companies with little or no experience in sourcing and dealing with foreign partners themselves. The company, in effect, was able to reduce the shortcomings that lack of experience or ignorance would have caused a local firm attempting the practice for the first time. The organization also ensures that a good working relationship is maintained. The role of social relationships in the offshore outsourcing is valued more to the Finnish side than the contract. On the other hand, the Indian software house is looking for partners that are able to pay them handsomely, treasure their expertise and continue to use them in the future. To this end, the Indian software upgrades its skills or knowledge base; and at the same time does not downplay the need to value good and efficient communications and trust, which they believe will generate customer satisfaction. This findings is supported by the work of Gottschalk and Solli-Sæther [92] (p200) who stated that "relationships focus on economic benefits, then 
there are concerns about access to competence, and finally the development of norms and alliance management are the main focus".

Additionally, the Indian software came into the arrangement with the Finnish partners with its technical expertise, which the clients apparently appreciated. The reasons for its involvement in offshore outsourcing arise from the fact that the software house has the required skills and expertise, which is in demand in Finland. Moreover, the Indian software house was able to secure the contract in Finland through its earlier contacts with the Finnish software broker house. The management of the Indian firm treasure customer satisfaction and cost savings for its client as well as the provision of high quality and innovative products. However, the organisation's main problems emanates from the differences between the two countries. Specifically, the Finnish side notes misunderstandings in communication. Notwithstanding, this problem did not affect the system development project in any way, as the software broker house is familiar with the Indian way of expressing themselves, after having made several visits to India. Furthermore, since the type of project that they are engaged with is 'cultureneutral', no major problems were seen. Visa procurement for the Indian workers was another glitch, which the broker house was able to attend to. The importance of efficient communication, enabled by technology, facilitated smooth relations with India's Finnish clients.

The implications of this study are twofold: First, practitioners can benefit from the knowledge that a broker house experienced in marketing, management and software development can bring by acting as a buffer between foreign vendor(s) and local firms that are less versed in the matters of global outsourcing or that are simply risk averse. The highlight from this study clearly shows the role of such software broker houses. Their ability to use contacts and past experience in selecting the right partners for clients is worthwhile. The revelation of this study is that the software broker house did not only act as 'sourcer' of required partners overseas, they actually partook in the systems development process all the way. This increases confidence for the local partners and the foreign supplier, which further engenders good relationships. Second, the study contributes to the growing body of knowledge in offshore outsourcing from the perspective of two players in the global software industry; namely Finland and India. Mainly, the findings of the study support other studies wherein the imperatives for offshore outsourcing are presented. For example, it was noted that offshore outsourcing tends to be problem-free when good relations are maintained, effective communication is kept, all parties trust one another and minor differences in linguistic abilities are not overblown.
Additionally, systems development projects that are 'culture-neutral' thrive and proceed smoothly despite cross-national or cultural differences. In the same vein, the single contract, in which performances and milestones are measured, rather than the rolling type, has worked well for this partnership. On the whole, this study extends our knowledge through empirical evidence about the practice of offshore outsourcing by the multiple case studies from two countries in the global software industry.

The main limitation of the study is that the richness of the information received could be influenced by response bias, as each of the participating companies is aware that similar questions are being sought from their partners. As such, one cannot rule out the possibility that some responses might have appeared more appealing than they otherwise would have under differing circumstances. Moreover, as the study is prone to that shortcoming, generalizing from this case study to all offshore outsourcing of systems development involving the two countries cannot be and has not been made. Future research from the two countries can explore in depth the factors or considerations that lead to retention of offshore partners and which practices or behaviors may lead to switching to alternative sources. In addition, the role of inexperienced management in building confidence in the offshore outsourcing of systems development projects, especially at the earlier stages, can be explored. Also, as the companies used in this particular study are small and medium-sized, an investigation of offshore outsourcing between the two countries using large firms may present new findings.

\section{REFERENCES}

1. Correa, C., Strategies for software exports from developing countries. World Development, 1995. 24(1): p. 171-82.

2. The Outsourcing Institute, Outsourcing Index 2001, in 27/3/2004, http://www.outsourcing.com, Editor. 2004: $12 / 6 / 2005$.

3. Greenemeier, L., Offshore Outsourcing Grows to Global Proportions, in http://www.informationweek.com/story/IWK2002 0207S0011, Informationweek.com, Editor. 2002: February 11/ 2002.

4. Patane, J.R. and J. Jurison, Is Global Outsourcing Diminishing the Prospects for American Programmers? Journal of Systems Management, 1994. 45(6): p. 6-10.

5. Heeks, R., Gobal Software Outsourcing to India by Multinational Corporations, in Global Information Technology and Systems Management: Key Issues and Trends, C.S. 
Palvia and E.M. Roche, Editors. 1996a: Ivy League Publishing, Limited. p. 365-392.

6. Carmel, E., Taxonomy of New Software Exporting Nations. Electronic Journal of Information Systems in Developing Countries, 2003a. 13(2): p. 1-6.

7. Porter, M.E., Competitive Strategy. 1980, New York: The Free Press. 369.

8. Elmuti, D. and Y. Kathawala, The Effects of Global Outsourcing Strategies on Participants' Attitudes and Organizational Effectiveness., in Outsourcing and Downsizing in the Service Market. 2000., Bedford.

9. Lacity, M.C. and L.P. Willcocks, Global Information Technology Outsourcing: In Search of Business Advantage. 2001: John Wiley\& Sons Ltd.

10. Gupta, U.G. and A. Gupta, Outsourcing The IS Function: Is It Necessary for Your Organization? Information Systems Management, 1992. 9(3): p. 44-50.

11. Thomas D. Clark, J., Corporate systems management: an overview and research perspective

http://doi.acm.org/10.1145/129630.129633

Commun. ACM 199235 (2 ): p. 61-75

12. Bagchi, S., India's software industry: the people dimension. IEEE Software, 1999: p. 62-65.

13. Rajkumar, T.M. and R.V.S. Mani, Offshore Software Development. The View from Indian Suppliers., in Information Systems Management. 2001. p. 63-73.

14. Heeks, R.B., India's Software Industry,. 1996b, New Delhi: Sage Publications.

15. Ke, J.S. The Developing Software Industry of Taiwan. in Proceedings of the IEEE 13th. Annual Computer Software and Application Conferences. 1989. Orlando, Florida: IEEE computer society.

16. Rosencrance, L., IBM wins 10-year outsourcing deal from Indian telecom firm, in Computerworld. 2004.

17. Bahtanagar, S.C. and S. Madon, The Indian software industry: Moving towards maturity. Journal of Information Technology, 1997. 12(277-288).

18. Gupta, S., Demystifying offshore outsourcing Despite the risks, the benefits can be great. CMA Management, 2002. 76(8): p. 36-.

19. Smith, M.A., S. Mitra, and S. Narasimhan, Offshore outsourcing of software development and maintenance: A framework for issues. Information \& Management, 1996. 31(3): p. 165-175.

20. Carmel, E., The New Software Exporting Nations: Success Factors. Electronic Journal on Information Systems in Developing Countries, 2003b. 13(4): p. 1-12.
21. Vijayan, J., Offshore Ops to Get Stronger Privacy Lock,. Computerworld, 2003.

22. Chen, Q. and B. Lin. Driving Factors and Strategic Concerns of Global IT Outsourcing: Perspectives of IT Society in Developing Countries. in Information Resource Management Association International Conference. 1998.

23. Smith, M.A., M. Sabyasachi, and S. Narasimhan, Offshore Outsourcing of Software Development and Maintenance: A Framework for Issues. Information and Management,, 1996. 31.(3): p. 165-175.

24. Rands, T., The key role of applications software make-or-buy decisions. Journal of Strategic Information Systems, 1992. 1(4): p. 215-223.

25. Williamson, O.E., The Economic Institutions of Capitalism: Firms, markets, Relational Contracting. 1985, New York: Free Press.

26. Willcocks, L.P., G. Fitzgerald, and M.C. Lacity, To Outsource IT or Not? Recent Research on Economics and Evaluation Practice. European Journal of Information Systems, 1996a. 5: p. 143-160.

27. Gurbaxani, V. and S. Whang, The impact of information systems on organizations and markets

http://doi.acm.org/10.1145/99977.99990

Commun. ACM 199134 (1): p. 59-73

28. Ang, S., Toward Conceptual Clarity of Outsourcing, in Business Process Reengineering: Information Systems Opportunities and Challenges, B.C. Glasson, Editor. 1994, Elsevier Science B.V. (NorthHolland). p. 113-126.

29. Feeny, D.F. and L.P. Willcocks, Core IS capabilities for exploiting information technology, in Sloan Management Review. 1998. p. 9-21.

30. Kern, T. and L.P. Willcocks, Exploring Information Technology Outsourcing Relationships: Theory and Practice. Journal of Strategic Information Systems, 2000. 9: p. 321350.

31. McFarlan, F.W. and L.R. Nolan, How to Manage an IT Outsourcing Alliance. Sloan Management Review, 1995. 36( 2).

32. Yalaho, A. A Conceptual Model of ICTSupported Unified Process of International Outsourcing of Software Production. in 10th IEEE International Enterprise Distributed Object Computing Conference Workshops (EDOCW'06). 2006. HongKong, China: IEEE Computer Society.

33. Cohen, L., Outsourcing Strategies and Challenges. 2003, Gartner Group publications. p. $23-27$.

34. Apte, U.M., et al., IS Outsourcing Practices in the USA, Japan and Finland: A Comparative 
Study. Journal of Information Technology, 1997. 12(4): p. 289-304.

35. Harindranath, G. and G. Dhillon, eds. International Outsourcing: Exploiting The Emerging Economy Option. Managing Information Technology Resources and Applications in The World Economy, ed. P. Hershey. 1997, Idea Group Publishing. 134-138.

36. Goff, L., US Programmer Shortage Spurns Offshore Software Development,. MIS Week, 1990. 11: p. January.

37. Ravichandran, R. and N.U. Ahmed, Offshore Systems Development. Informantion and Management, 1993. 24: p. 33-40.

38. Applegate, L.M. and R. Montealegre, Eastman Kodak: Managing Information Systems Through Strategic Alliances. 1991, Boston, MA: Harvard Business School.

39. Brown, B. and W. Eckerson, Kodak turns net over to IBM and DEC; farming out net operations can trigger staffing issues, in Network World. 1990. p. 61 -63.

40. Loh, L. and N. Venkatraman, Diffusion of Information Technology Outsourcing: Influence Sources and the Kodak Effect. Information Systems Research, 1992a. 3(4, (December)): p. 334-378.

41. Lacity, M.C. and R. Hirschheim, Implementing Information System Outsourcing: Key Issues and Experiences of an Early Adopter. Journal of General Management, 1993b. 19(1 (Autumn)): p. 17-31.

42. Lacity, M.C. and R. Hirschheim, Information Systems Outsourcing: Myths, Metaphors, and Reality. 1993a, New York, NY: John Wiley and Sons.

43. Bhatnagar, S.C. and S. Madon, The Indian Software Industry: moving towards maturity. Journal of Information Technology, 1997. 12: p. $277-288$.

44. Taylor, P., India's software industry. Financial Times Review of information Technology, 1996: p. 1-6.

45. Athreye, S.S., The Indian software industry and its evolving service capability 10.1093/icc/dth056. Ind Corp Change, 2005. 14(3): p. 393-418.

46. EconomicTimes, India's IT, software industry upbeat on future, in THURSDAY, MARCH 29, $2007 \quad 11: 45: 08 \quad A M]$, http://economictimes.indiatimes.com/Indias IT software industry upbeat on future/RssArticle Show/articleshow/1826703.cms, Editor. 2007: 20/04/2007.

47. GartnerDataquest, Gartner Dataquest Says Worldwide Software Spending to Stabilize in 2003: Spotlight Report Examines Trends for the
Software Industry. 2003, Gartner Group publications.

48. International Data Corporation (IDC), IDC Predictions 2007: Prospering in Era of Hyperdisruptionb (IDC \#204631). 2006, International Data Corporation.

49. Toivanen, H., Software Innovation in Finland, in Working Papers No. 52, VTT Group, Finland. 2000.

50. Autere, J., Lamberg, I., Tarjanne, A. . Ohjelmistotuotteilla kansainväliseen menestykseen. Toimialan kehittämistarpeet ja toimenpide-ehdotukset., in Tekes, Teknologiakatsaus 74/99. 1999.

51. UK Trade and Investment, in 23/3/2004, http://search1.tradepartners.gov.uk/software/finla nd2/profile/overview.shtml, Editor. 2004.

52. Eastern Michigan University publication, Finland, http://www.emich.edu/ict usa/FINLAND.htm, Editor. 2004: 26/3/2004.

53. Lassila, A., et al., Finnish Software Product Business: Result of the National Software Industry Survey 2006, ed. C.o.E.f.S.P. business. 2006, Helsinki: Hesinki Univeristy of Technology.

54. Dutta, S., L. Bruno, and F. P., eds. The Global Information Technology Report: Readiness for the Networked World. World Economic Forum. 2003, Oxford University Press: New York.

55. Delhi Information online, http://www.delhiinfo.com/new/indiansoftware1. htm., Editor. 2004: 28/4/2004.

56. Kshetri, N., Economics of Linux Adoption in Developing Countries. IEEE Software, 2004. 23(1): p. 74-81.

57. Brean Murray \& Company, India Sees IT Growth, http://www.bmur.com/, Editor. 2004: $15 / 5 / 2005$.

58. Nasscom, Nasscom's India-Europe Software Alliance Seminar Report. 1995: London.

59. Pandely, V. and V. Bansal. A Decision-Making Framework for IT Outsourcing using the Analytic Hierarchy Process. in International Conference on Systemics, Cybernetics,Informatics. 2004. NISIET, Govt. of India, Hyderabad.

60. Chordas, L., Eyes on India. (Technology: Global Outsourcing).(companies are outsourcing work to India), in Best's Review. 2003: 01-MAY-03.

61. NASSCOM, Fact Sheet, NASSCOM 2007 Knowledge Professionals in India. 2007, NASSCOM: India.

62. Udell, J., India's Software Edge, in Byte. 1993. p. 55-60.

63. Heeks, R., Gobal Software Outsourcing to India by Multinational Corporations, in Global Information Technology and Systems 
Management: Key Issues and Trends, C.S. Palvia and E.M. Roche, Editors. 1996: Ivy League Publishing, Limited. p. 365-392.

64. Dahlman, $\mathrm{C}$. and $\mathrm{A}$. Utz, India and the Knowledge Economy: Leveraging Strengths and Opportunities, in WBI DEVELOPMENT STUDIES. 2005, The World Bank: Washington, D.C., USA.

65. Mehta, V., Outsourcing to India. Mortgage Banking, 2002. 62(12): p. 76-84.

66. Nagy, H., Exploiting information technology for development: A case study of India, in World Bank Discussion Paper No. 246. 1994, The World Bank: Washington DC.

67. Davey, H. and B. Allgood, Offshore development, building relationships across international boundaries:

A case study. Information Strategy: The Executive's Journal, 2002. 18(3): p. 13-16.

68. Nahar, N., T. Käkölä, and N. Huda. Software Production in Developing and Emerging Countries through International Outsourcing. in Proceedings of the Information and Communication Technologies and Development: New Opportunities, Perspectives \& Challenges, 7th International Working Conference of IFIP WG 9.4, S. 2002. Bangalore, India: Indian Institute of Management Bangalore.

69. Krishna, S., S. Sahay, and G. Walsham, Managing cross-cultural issues in global software outsourcing

http://doi.acm.org/10.1145/975817.975818

Commun. ACM 200447 (4 ): p. 62-66

70. Cullen, J., Multinational Management: A strategic Approach. 1999, Cincinatti, OH.: South Western College Publishing.

71. Bensaou, B.M., Portfolios of Buyer-Supplier Relationships. Sloan Management Review, 1999. 40(4): p. 35-44.

72. Currie, W.L. and L.P. Willcocks, New Strategies in IT Outsourcing: Major Trends and Global Best Practices. 1997, London.

73. Khan, N., et al. Evaluating Offshore IT Outsourcing in India: Supplier and Customer Scenarios. in hicss. 2003. Hawaii, USA.

74. Kakabadse, A. and N. Kakabadse, Trends in Outsourcing: Contrasting USA and Europe. European Management Journal, 2002. 20(2): p. 189-198.

75. Cook, T.D. and D.T. Campbell, QuasiExperimentation, Design and Analysis Issues for Field Settings. 1979, Boston: Houghton Mifflin.

76. Yin, R., Case Study Research: Design and Methods. 2nd edition. 1994, California.: Beverly Hills: Sage Publications.

77. Miles, M.B. and A.M. Huberman, Qualitative Data Analysis: An Expanded Sourcebook. 2nd edition ed. Calif. 1994: Thousand Oaks, Sage.
78. Richards, L., Handling Qualitative Data: A Practical Guide. 2005: Sage Publications Ltd. 224.

79. Richards, L., Using NVivo in qualitative research. 1999, London: Sage.

80. Richards, L., Using NVivo in Qualitative Research'. 3 ed. 2002: Qualitative Solutions and Research Publications.

81. Strauss, A. and J. Corbin, Basics of Qualitative Research: Grounded Theory Procedures and Techniques. 1990, Newbury Park, CA: Sage Publications.

82. Auerbach, C.F., Qualitative Data : An Introduction to Coding and Analysis. 2003, New York, NY, USA: New York University Press.

83. MacQueen, K.M., et al., Codebook Development for Team-Based Qualitative Analysis. Cultural Anthropology Methods, 1999. 10(2): p. 31-36.

84. Nahar, N., Information Technology Supported Technology Transfer Process: A Multi-site Case Study of High-tech Enterprises, in Jyväskylä Studies in Computing 9. 2001, Jyväskylä University: Jyväskylä.

85. Stake, R.E., The Art of Case Study Research. 1995, CA.: Thousand Oaks, Sage,

86. Patton, M.Q., Qualitative evaluation and Research Methods. 2 ed. 1990: Sage Publications.

87. Wang, E.T.G., T. Barron, and Seidmann, Contracting Structures for Custom Software Development: The Impacts of Informational Rents and Uncertainty of Internal Development and Outsourcing. Management Science, 1997. 43(12).

88. Whang, S., Contracting For Software Development. Management Science, 2001. 38(3): p. 307 - 324.

89. Sabherwal, R., The role of trust in outsourced IS development projects

http://doi.acm.org/10.1145/293411.293485

Commun. ACM 199942 (2 ): p. 80-86

90. Granovetter, M., Economic Action and Social Structure: The Problem of Embeddedness. American Journal of Sociology, 1985. 91(3): p. 481-510.

91. Easton, G., Industrial Networks, in Industrial Network: A new view of reality, J. Elam, et al., Editors. 1992, Routledge: London.

92. Gottschalk, P. and H. Solli-Sæther, Maturity model for IT outsourcing relationships. Industrial Management \& Data Systems, 2006. 106(2): p. 200 - 212.

93. Gurbaxani, V., The new world of information technology outsourcing. Commun. ACM, 1996. 39(7): p. 45-46.

94. Jiang, J.J. and G. Klein, User evaluation of information systems: by system typology; TSMCA, 1999: p. 111-116. 
95. Baker, S., Calling all nerds, in Business Week. 1997.

96. Earl, M., Limits to IT Outsourcing. 1996, London Business School, Centre for Research on Information Management: London.

97. Herbsleb, D.J. and D. Moitra, Global Software Development, in IEEE Software. 2001.

98. Lacity, M.C., R. Hirschheim, and L. Willcocks, Realizing Outsourcing Expectations. Information Systems Management, 1994. 11(4 (Fall)): p. 718.

99. Grover, V., M.J. Cheon, and J.T.C. Teng, The Effect of Service Quality and Partnership on the Outsourcing of Information Systems Functions. Journal of Management Information Systems: JMIS, 1996. 12(4 (Spring)): p. 89-116.

100.Quinn, J.B., Strategic Outsourcing: Leveraging Knowledge Capabilities. Sloan Management Review, 1999. 40(4): p. 9-21.

101.Bettis, R.A., S.P. Bradley, and G. Hamel, Outsourcing and Industrial Decline. Academy of Management Executive, 1992. 6(1 (February)): p. 7-22.

102.Kobitzsch, W., D. Rombach, and R.L. Feldmann, Outsourcing in India [software development]. Software, IEEE, 2001. 18(2): p. 78-86.

103.Jonash, R.S., Strategic technology leveraging: making outsourcing work for you. Research Technology Management, 1996. 39(2).

104.Yesulatitis, J.A., Outsourcing for new technology adoption. Information Systems Management, 1997. 14(2): p. 80-82.

105.Yalaho, A., et al. IT-Supported International Outsourcing of Software Production: An Explorative Case Study. in Proceedings of the 14th Information Resources Management Association International Conference. 2004. June, New Orleans, US.

106.Loh, L. and N. Venkatraman, Determinants of Information Technology Outsourcing: A CrossSectional Analysis. Journal of Management Information Systems, 1992b. 9(1): p. 7-24.

107.Durand, D. and J. Iyengar. Exploratory Study of International Outsourcing Contract Programming for the Computer Industry: What? Why? Who? in Proceedings- Southeast Region Decision Science Institute, Twenty-first Annual Meeting. 1991. Arlington, Virginia.

108.Alpar, P. and A.N. Saharia, Outsourcing Information Systems Functions: An Organizational Economics Perspective. Journal of Organizational Computing, 1995. 5(3): p. 197-217.

109.Parker, M., R. Benson, and E. Trainor, Information economics: linking business performance to information technology. 1988, New Jersey: Prentice Hall.
110.Joshi, K. and V. Sauter, The opportunities and constraint affecting an informatics policy: The India experience. Information and Management, 1991. 20(5): p. $313-322$.

111.Heeks, R., India's Software Industry, State Policy, Liberalisation and Industrial Development. 1996a, New Delhi: Sage Publications.

112.Loh, L. and N. Venkatraman, Diffusion of Information Technology Outsourcing: Influence Sources and the Kodak Effect. Information Systems Research, 1992b. 3(4): p. 334-358.

113.Benko, C., Outsourcing Evaluation: A Profitable Process. Managing Information Technology Investments with Outsourcing. 1995: IDA Group Publishing. 190.

114. Bhattacharya, S., R.V. Behara, and D.E. Gundersen, Business risk perspectives on information systems outsourcing. International Journal of Accounting Information Systems, 2003. 51( 1- 18).

115.Lacity, M.C. and R. Hirscheim, The Information Systems Outsourcing Bandwagon. Sloan Management Review, 1993. 35(1 (Fall)): p. 7386.

116.Loh, L. and N. Venkatraman, Determinants of information technology outsourcing: a crosssectional analysis J. Manage. Inf. Syst. , 19929 (1): p. 7-24

117.Schwartz, J., Offshore Politics Hit Home. Varbusiness, 2004. 20(6): p. 22.

118. Thibodeau, P., Offshore outsourcing is relentless. 2003, Computerworld.

119.Heeks, R., Global Software Outsourcing to India by Multinational Corporations, in Global Information Technology and Systems Management, P. Pavlia, S. Pavlia, and E. Roche, Editors. 1996b, Ivy League Publishing: Nashua, $\mathrm{NH}$.

120.Czepiec, H. and Landers. Skill requirement for a global force: The International business employers' perspective,. in Proceeding of Western DSI Annual Conference. 1996.

121.Vijayan, J., Offshore outsourcing poses privacy perils. Computer World, 2004. 38(8): p. 10-

122. Richmond, W.B. and A. Seidmann, Software Development Outsourcing Contract: Structure and Business Value. Journal of Management Information Systems, 1993. 10(1): p. 57 - 72.

123. Whang, S., Contracting For Software Development. Management Science, 2001. 38(3): p. 307 - 324.

124. Aubert, B.A., M. Patry, and S. Rivard, A Tale of Two Outsourcing Contracts. 1997, Cahier du GreSI,.

125.Nahar, N., IT-enabled Effective and Efficient International Technology Transfer for SMEs, in Evolution and Challenges in System 
Development., I.J. Zupancic, et al., Editors. 1999, Kluwer Academic/Plenum Publishers: New York, USA. p. 85-98.

126.Khan, N., et al. Evaluating Offshore IT Outsourcing in India: Supplier and Customers Scenarios,. in Proceedings of the 36th. Hawaii International Conference on Systems Sciences. 2003. USA.

127.Carmel, E., Global Software Teams: Collaborating Across Borders and Time Zones. 1999, NY: Prentice Hall.

128.Lacity, M.C., L.P. Willcocks, and D.F. Feeny, IT Outsourcing: Maximize Flexibility and Control. Harvard Business Review, 1995(May-June): p. 84-93.
129.Dorn, P., Selling One's Birthright, in Information Week. 1989.

130.Lacity, M. and R. Hirschheim, The Information Systems Outsourcing Bandwagon. Sloan Management Review,, 1993. 35(1): p. 73 - 86.

131.Brij, R., Software Exports: The European Opportunity, in Computer Today. 1994.

132.Momme, J., Framework for Outsourcing: Based on Theoretical Review and Empirical Findings from Danish Heavy Industry., in Hvolby, H.H., ed. The Fourth SMESME International Conference. 2001: Denmark: Department of Production, Aalborg University,.

\section{TABLES AND FIGURES}

Table 1. Summary of the drivers and benefits of offshore outsourcing

\begin{tabular}{|c|c|c|}
\hline Outsourcing drivers & Benefits sought & \\
\hline Dearth of skilled IT professionals & The urge to overcome shortage of IT professionals in the West & $\begin{array}{l}\text { Reterences } \\
{[4,22,60,93-} \\
95]\end{array}$ \\
\hline $\begin{array}{l}\text { Proximity to the market, global } \\
\text { presence and accelerated delivery }\end{array}$ & $\begin{array}{l}\text { Getting close to market and the opportunity to expand } \\
\text { business operations through partnered joint-ventures and } \\
\text { collaborations }\end{array}$ & $\begin{array}{l}{[17,18,22,} \\
96,97]\end{array}$ \\
\hline Core competency & $\begin{array}{l}\text { Outsourcing non-core business functions, thereby enabling } \\
\text { firms to focus on core activities }\end{array}$ & {$[11,98-101]$} \\
\hline $\begin{array}{l}\text { Technological and technical } \\
\text { know-how }\end{array}$ & $\begin{array}{l}\text { The impetus to gain expertise in emerging technologies not } \\
\text { currently available in-house and/or locally. Access to good } \\
\text { quality jobs and project management skills. }\end{array}$ & $\begin{array}{l}{[31,93,102-} \\
106] .\end{array}$ \\
\hline $\begin{array}{l}\text { Cost advantages } \\
-\quad \text { Economies of scale } \\
\text { - Quality }\end{array}$ & $\begin{array}{l}\text { Exploiting low wages and costs of foreign software houses. } \\
\text { The availability of high quality, reliable and flexible systems } \\
\text { development, which above all is cheaper than home countries' } \\
\text { offers }\end{array}$ & {$[99,107-113]$} \\
\hline Environmental reasons & $\begin{array}{l}\text { - Overcoming the impact of weak economic situations, } \\
\text { in the face of global competition } \\
\text { - The imitative behaviour among firms to jump onto } \\
\text { the bandwagon } \\
\text { - Overcoming developmental constraints }\end{array}$ & $\begin{array}{l}{[22,31,35} \\
93,114-116]\end{array}$ \\
\hline
\end{tabular}


Table 2. Summary of the inhibitors and obstacles of offshore outsourcing

\begin{tabular}{|c|c|c|}
\hline $\begin{array}{l}\text { Offshore outsourcing } \\
\text { inhibitors }\end{array}$ & Obstacles explanations & References \\
\hline Government restrictions & $\begin{array}{l}\text { Governments of (local and foreign partners) may impose } \\
\text { unfavourable conditions. For example, in visa procurement } \\
\text { or outright protectionism. }\end{array}$ & $\begin{array}{lll}22, & 35, & 117- \\
119] & \end{array}$ \\
\hline Linguistic considerations & $\begin{array}{l}\text { The inability to use a common medium of communication is } \\
\text { inimical. The use of English for some countries has turn out } \\
\text { to be a blessing, the lack of it problematic to others. }\end{array}$ & $\begin{array}{l}{[13,18,22,60} \\
65,111,120 \\
121]\end{array}$ \\
\hline Legal/contractual problems & $\begin{array}{l}\text { Each country has its own peculiar legal systems. The } \\
\text { absence of uniformity in law makes the drawing up and } \\
\text { enforcing contractual agreements difficult. }\end{array}$ & $\begin{array}{l}{[22,87,96,102,} \\
122-124]\end{array}$ \\
\hline $\begin{array}{l}\text { IT infrastructure and } \\
\text { telecommunications } \\
\text { problems }\end{array}$ & $\begin{array}{l}\text { The availability of IT infrastructure is advantageous } \\
\text { facilities available. The lack of it is inimical. }\end{array}$ & $\begin{array}{l}{[18,34,65,68,} \\
125]\end{array}$ \\
\hline The influence of national culture & $\begin{array}{l}\text { The differing nature of culture may impact upon operations } \\
\text { in offshore outsourcing negatively. }\end{array}$ & {$[21,22][34,69]$} \\
\hline $\begin{array}{l}\text { Intellectual Property Right (IPR) } \\
\text { violations, security and trust } \\
\text { issues }\end{array}$ & $\begin{array}{l}\text { Adherence to IPR rules vary across the globe. This is a } \\
\text { source of conflict in offshore outsourcing. When } \\
\text { confidentiality is breached, organisations (customers) may } \\
\text { loose mission critical information. }\end{array}$ & {$[22,34,126]$} \\
\hline $\begin{array}{l}\text { Time-zone differences, time } \\
\text { differences in working hours and } \\
\text { distance }\end{array}$ & $\begin{array}{l}\text { Differences in time zones and working hours could be an } \\
\text { advantage and, at the same time a limitation. }\end{array}$ & {$[21,34,127]$} \\
\hline The danger of opportunism & $\begin{array}{l}\text { Offshore outsourcing faces imminent threats when partners } \\
\text { take advantage of clients or fail to provide cost reduction } \\
\text { advantages, quality improvement. Or hidden cost is not } \\
\text { controlled etc. }\end{array}$ & $\begin{array}{l}{[13,73,93,96,} \\
128]\end{array}$ \\
\hline Geo-political risks & $\begin{array}{l}\text { Offshore outsourcing may be stalled, if conflicts break out in } \\
\text { a partners' site }\end{array}$ & {$[65,73,96]$} \\
\hline $\begin{array}{l}\text { Lack of specific technological } \\
\text { skills }\end{array}$ & $\begin{array}{l}\text { A foreign partner may lack expertise in certain cutting-edge } \\
\text { technologies that may not be disclosed. }\end{array}$ & {$[21,96,128]$} \\
\hline $\begin{array}{l}\text { Loss of organisational } \\
\text { competencies and control over } \\
\text { projects }\end{array}$ & $\begin{array}{l}\text { As firms seamlessly outsource non-core functions to } \\
\text { offshore sites, they gradually reduce their expertise in such } \\
\text { areas. Moreover, the loss of control over development } \\
\text { projects also ensues. }\end{array}$ & $\begin{array}{lll}73,96, & 129- \\
131]\end{array}$ \\
\hline $\begin{array}{ll}\text { Managerial considerations } \\
\text { - } & \text { Financial stability } \\
\text { - } & \text { Project management } \\
& \text { skills } \\
\text { - } & \text { Company size and other } \\
& \text { facilities }\end{array}$ & $\begin{array}{l}\text { Offshore partners are often evaluated on the basis of their } \\
\text { project management skills, achievements, reputation and } \\
\text { other available resources in order to assess the obstacles. } \\
\text { Conflict may ensue when deviations are noticed. }\end{array}$ & $\begin{array}{l}{[13,19,21,22,} \\
29,31,37,67, \\
132]\end{array}$ \\
\hline
\end{tabular}

